DOI: http://dx.doi.org/10.18203/2320-1770.ijrcog20190047

Case Report

\title{
Prolapse in pregnancy
}

\section{Indrani Dutta*, Jacinta Minz}

Department of Obstetrics and Gynecology, RIMS, Ranchi, Jharkhand, India

Received: 30 December 2018

Accepted: 07 January 2019

\author{
*Correspondence: \\ Dr. Indrani Dutta, \\ E-mail: docdutta2018@gmail.com
}

Copyright: (c) the author(s), publisher and licensee Medip Academy. This is an open-access article distributed under the terms of the Creative Commons Attribution Non-Commercial License, which permits unrestricted non-commercial use, distribution, and reproduction in any medium, provided the original work is properly cited.

\begin{abstract}
Presentation of uterine prolapse is a normal event in a pregnant woman which can be pre-existent or else manifest in the course of pregnancy. Complications resulting from prolapse of uterus vary from minor cervical infection to spontaneous abortion to preterm labour, maternal and fetal mortality, acute retention of urine and urinary tract infection. Authors of this paper have studied a case of a pregnant lady who presented to the emergency department with prolapse and her line of management which was executed. This was a case report study and management were done as per standard obstetrical guidelines. Patient was counselled at the time of discharge. Implementation of conservative treatment modalities throughout pregnancy with prolapse and their application in accordance of severity of uterine prolapse and patient's preference may be sufficient to achieve an uneventful pregnancy, normal and spontaneous vaginal delivery.
\end{abstract}

Keywords: Delivery, Dystocia, Pessary, Prolapse

\section{INTRODUCTION}

The rising number in literature of pelvic organ prolapse in pregnancy has been observed. However, little is known about the incidence of pelvic organ prolapse during pregnancy, as there is a lack of documentation and standardization in the diagnosis. Historically, the treatment of prolapse, especially cervical prolapse, has evolved from interruption of pregnancy and setting fire to the cervix, to pessary use.

The mounting awareness of the incidence of such disease entity in pregnancy has led to the need to document cases in order to have a deeper understanding, and in effect, possible prevention of future complications both during pregnancy and in advanced years after the pregnancy. Studies have postulated that pregnancy, labor, and vaginal delivery have a negative impact on the pelvic floor, especially the pudendal nerve, predisposing parous women to pelvic organ prolapse in the subsequent pregnancies. A review by Dietz and Wilson in 2005 addressed this issue by considering the following:

- Adverse effects on nerve structure and function.

- Adverse effects on pelvic floor muscle structure and functions.

- Adverse effects on pelvic organ support.

- Epidemiological evidence linking childbirth to incontinence and prolapse.

- It is also noteworthy to mention that changes in the pelvic support during pregnancy itself would predispose a parturient to prolapse during the pregnancy.

De Lancey has also identified these defects according to the levels of support in 1992. He identified the three levels of pelvic support, the uterosacral-cardinal ligament complex (Level I), the paravaginal supports namely pubocervical and rectovaginal fascia (Level II), and perineal membrane and perineal body (Level III). The 
accompanying the symptomatology of the prolapse may be explained by the defects in the supports. The symptom common to all types of prolapse is usually an introital mass or vaginal bulge. Pelvic Organ Prolapse is staged using the International Continence Society (ICS) Pelvic Organ Prolapse Quantification System (POP-Q) which was introduced in 1996. This staging presents a standard system of terminology approved by the International Continence Society, the American Urogynecologist Society, and the Society of Gynaecologic Surgeons in describing the female pelvic organ prolapse and pelvic floor dysfunction. It is an objective site-specific system for describing, quantitating, and staging pelvic support in women is included. POP-Q introduces the 9-point grid, which identifies the different compartments of the pelvis.

Is the present pregnancy itself especially in the nulliparous predisposes to pelvic organ prolapse? Is the delivery process and the pelvic changes responsible? Will a pregnancy predispose the future ones to puerperal prolapses? What are the complications of a pregnancy that is accompanied by a pelvic organ prolapse? Following is a case report about pelvic organ prolapse complicating a pregnancy and its management.

Literature review of prolapsed describes clinical features of pelvic pressure. low back ache, urinary tract symptoms, cervical inflammation, cervical mucosal ulcerations. Complications range from patient discomfort, cervical desiccation and ulceration, urinary tract infection, acute urinary retention, miscarriage and maternal death. In times immemorial Chinese doctors treated prolapse by wrapping the prolapsed part with kerosene oil and setting fire to it. But medical science has come a long way. At present day context best management is reduction of prolapsed during antenatal period and bed rest in Trendelenburg position. (ref: Piver and Spezia, Daskalakis et al). ${ }^{1,2}$ After reduction placement of well fitted lever /doughnut pessary (Sawyers, Piver and Spezia et al). ${ }^{3}$ The mode of delivery is also a concern in this case. It is apparent that over the years, normal vaginal deliveries have increased and the need for forceps has decreased.

\section{CASE REPORT}

Mrs. Phulmati, 37 years, G5P4+0L4, presented to labour room RIMS with term pregnancy and pain abdomen since $6 \mathrm{hrs}$ prior to her time of admission. Her pulse rate was 86/min and blood pressure 120/70 $\mathrm{mm} \mathrm{Hg}$. Her b/l lung fields were clear and S1, S2 were normal with no added sounds, she was moderately pale. On per abdomen examination uterus was term size, cephalic, with mild contractions. FHR was $136 \mathrm{bpm}$ in left spinoumblical line and head was $4 / 5$ palpable. On per vaginum examination parous os was present, head was high and membranes present. She was allowed to progress for spontaneous labour as she had all prior normal deliveries. Progressively there was onset of stronger uterine contractions $\left(3 / 45 "-60 " / 10^{\prime}\right)$. As her labour progressed cervix was visible outside vaginal introitus. The cervical protrusion gradually increased with progression of labour She was enquired about any history of prolapse in her prior pregnancies or in her current antenatal period, but no such history could be inferred. Gradually there was descent of fetal head into prolapsed cervix and vagina and fetal scalp hair was visible through partially dilated os. Along with os there was a $2 \mathrm{~cm}$ rent at 2 o'clock position on the anterior cervical lip and fetal scalp hair was visible through the rent (Figure 1). Delivery had to be expedited as early as possible as there was partial cervical dilatation along with rent anteriorly in the cervix. Incision was given starting from os to cervical aperture. Delivery was uneventful, and an alive term male baby was borne by vertex. Baby cried just after birth. Active management of third stage of labour was done. Placenta and membranes taken out completely. Uterus was well contracted. Cervical was repaired with interrupted mattress sutures and reposed inside the introitus.

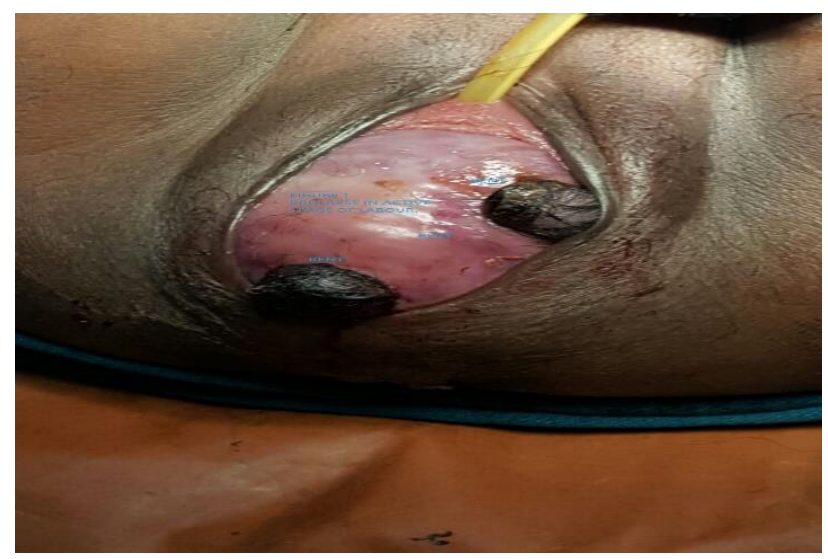

Figure 1: Prolapse in active stage of labour showing two rents.

Patient was observed for 1 week and then discharged. She was advised high protein diet, iron, vitamin and calcium supplements. Puerperium was uneventful. After puerperium in her next follow-up a ring pessary was inserted as it was a second-degree descent and did not want any surgical management. Further follow-up was done, and ICS was done postpartum (Table1).

Table 1: Postpartum ICS at 10 weeks postpartum.

\begin{tabular}{|l|l|l|}
\hline Aa-2 & Ba-2 & C-4 \\
\hline GH-5 & Pb2 & Tvl-9 \\
\hline Ap-1 & Bp-1 & D6 \\
\hline
\end{tabular}

\section{DISCUSSION}

Literature review shows that the majority of women are delivered by normal vaginal delivery the following table shows a comparison of papers which discussed the use of various vaginal pessaries to treat uterine prolapse during pregnancy. 
Table 2: Indication of pessary use in prolapse.

\begin{tabular}{|c|c|c|c|}
\hline Author & $\begin{array}{l}\text { Type of } \\
\text { pessary }\end{array}$ & Indication & Comments \\
\hline $\begin{array}{l}\text { Sawyer et } \\
\mathrm{al}^{3}\end{array}$ & $\begin{array}{l}\text { Hodge } \\
\text { pessary }\end{array}$ & $\begin{array}{l}\text { Mild uterine } \\
\text { prolapse with } \\
\text { retroversion }\end{array}$ & $\begin{array}{l}\text { Restored } \\
\text { prolapse }\end{array}$ \\
\hline $\begin{array}{l}\text { Piver et al } \\
\text { and Spezia } \\
\text { et } \mathrm{al}^{1}\end{array}$ & $\begin{array}{l}\text { Doughnut, } \\
\text { pessary }\end{array}$ & $\begin{array}{l}\text { Second and } \\
\text { third degree } \\
\text { prolapse }\end{array}$ & $\begin{array}{l}\text { Restored } \\
\text { prolapse }\end{array}$ \\
\hline $\begin{array}{l}\text { Daskalakis } \\
\text { et } \mathrm{al}^{2}\end{array}$ & $\begin{array}{l}\text { Hodge } \\
\text { (lever } \\
\text { pessary) }\end{array}$ & $\begin{array}{l}\text { Mild uterine } \\
\text { prolapse with } \\
\text { retroversion }\end{array}$ & $\begin{array}{l}\text { Restored } \\
\text { prolapse }\end{array}$ \\
\hline Yogev et $\mathrm{al}^{4}$ & $\begin{array}{l}\text { Ring } \\
\text { pessary }\end{array}$ & $\begin{array}{l}\text { First and } \\
\text { second } \\
\text { degree } \\
\text { prolapse }\end{array}$ & Fell out \\
\hline
\end{tabular}

Low incidence of pelvic organ prolapse complicating a pregnancy is probably due to lack of proper documentation and reporting. However, due to the increasing awareness and better understanding of the pathophysiology of pelvic organ prolapse, coinciding with the use of a uniform scoring system, the incidence of this disease entity is slowly rising. Pregnancy has long been known as a risk factor in the development of the pelvic organ prolapse, although its detection is done during the postmenopausal years, where the other factors that affect pelvic support come into play. Pelvic organ prolapse in pregnancy is considered high risk due to the risk of early and late prenatal losses or premature labor. Other observed complications may include urinary tract infection, urinary retention, maternal sepsis is some of the more severe events that can be correlated with pelvic organ prolapse. However, it is essential for the obstetrician to look out for the presence of cervical inflammation or oedema which may complicate a vaginal delivery, especially if there is inadequate time for sufficient antepartum treatment. Daskalakis 1 in 2007 suggested elective Caesarean section near term to avoid further pelvic floor damage, especially where the cervix is oedematous elongated. Therefore, obstetricians need to look out for these complications in a timely manner.

Table 3: Pessary use in pregnancy and their outcome.

\begin{tabular}{|c|c|c|c|c|}
\hline Author & No. of patients & Delivery & Infant & Complications \\
\hline \multirow{8}{*}{ Piver MS and Spezia $\mathrm{J}$ et al ${ }^{1}$} & \multirow[t]{8}{*}{ 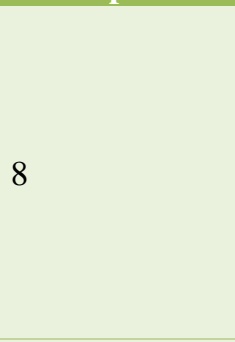 } & SVD & alive & \multirow{8}{*}{ Cervical laceration } \\
\hline & & SVD & alive & \\
\hline & & SVD & alive & \\
\hline & & C section & alive & \\
\hline & & SVD & alive & \\
\hline & & SVD & alive & \\
\hline & & SVD & alive & \\
\hline & & SVD & alive & \\
\hline Lavery JP et $\mathrm{al}^{5}$ & 1 & SVD & alive & Prolonged labour \\
\hline Hill PS et al ${ }^{6}$ & 1 & SVD & alive & PROM \\
\hline \multirow{2}{*}{ Brown $\mathrm{HL}$ et al ${ }^{7}$} & \multirow{2}{*}{2} & SVD & alive & Pre-term \\
\hline & & SVD & alive & Pre-term \\
\hline Matsumoto et $\mathrm{al}^{8}$ & 1 & SVD & alive & 0 \\
\hline Yogev $\mathrm{Y}$ et al ${ }^{4}$ & 1 & SVD & alive & Induced labour at $40+1$ week \\
\hline Sawyer D et al ${ }^{3}$ & 2 & C Section & alive & Cervical laceration \\
\hline Guariglia $\mathrm{L} \mathrm{et} \mathrm{al}^{9}$ & 1 & SVD & alive & 0 \\
\hline Daskalakis $\mathrm{G}$ et $\mathrm{al}^{2}$ & 1 & SVD & alive & 0 \\
\hline Partsinevelos GA et al $^{10}$ & 1 & SVD & alive & 0 \\
\hline
\end{tabular}

\section{CONCLUSION}

Uterine prolapse in pregnancy is a rare occurrence and best managed conservatively. This is usually attained with bed rest and placement of an appropriate.

Funding: No funding sources Conflict of interest: None declared Ethical approval: Not required

\section{REFERENCES}

1. Piver MS, Spezia J. Uterine prolapse during pregnancy. Obstet Gynecol.1968;32:765-9.

2. Daskalakis G, Lymberopoulos E, Anastasakis E, Kalmantis K, Athanasaki A, Manoli A, et al. Uterine Prolapse complicating pregnancy. Arch Gynecol Obstet. 2007;276(4):391-23 
3. Sawyer D, Frey K. Cervical Prolapse During Pregnancy. J Am Board Fam Pract. 1999;13(3):2168.

4. Yogev Y, Horowitz ER, Ben-Haroush A, Kaplan B. Uterine cervical elongation and prolapse during pregnancy: an old unsolved problem. Clin Exp Obstet Gynecol. 2003;30(4):183.

5. Lavery JP, Boey CS. Uterine prolapse with pregnancy. Obstet Gynecol. 1973;42(5):681-36.

6. Hill PS. Uterine prolapse complicating pregnancy. A casereport. J Reprod Med 1984;29(8):631-3.

7. Brown HL. Cervical prolapse complicating pregnancy. J National Med Assoc. 1997;89(5):346.

8. Matsumoto $\mathrm{T}$, Nishi $\mathrm{M}$, Yokota $\mathrm{M}$, Ito $\mathrm{M}$. Laproscopic treatment of uterine prolapse during pregnancy. Obstet Gynecol. 1999;93(5 Pt 2):84.
9. Guariglia L, Carducci B, Botta A, Ferrazzani S, Caruso A. Uterine prolapse in pregnancy. Gynecol Obstet Invest. 2005;60(4):192-4.

10. Partsinevelos GA, Mesogitis S, Papantoniou N, Antsaklis A. Uterine prolapse in pregnancy: a rare condition anobstetrician should be familiar with. Fetal Diagn Ther. 2008;24(3):296-8.

Cite this article as: Dutta I, Minz J. Prolapse in pregnancy. Int J Reprod Contracept Obstet Gynecol 2019;8:734-7. 